NBER WORKING PAPER SERIES

\title{
RECENT MANUFACTURING EMPLOYMENT GROWTH: THE EXCEPTION THAT PROVES THE RULE.
}

\author{
Robert Z. Lawrence \\ Working Paper 24151 \\ http://www.nber.org/papers/w24151 \\ NATIONAL BUREAU OF ECONOMIC RESEARCH \\ 1050 Massachusetts Avenue \\ Cambridge, MA 02138 \\ December 2017
}

This paper reflects work undertaken in part for a project on manufacturing and inclusive growth sponsored in part by the MasterCard Center for Inclusive Growth and the Peterson Institute for International Economics. I am very grateful for comments from Martin Baily, Olivier Blanchard, Robert Gordon, Ted Moran, Paul Solman, Ted Truman, and Nicolas Veron and for editing suggestions from Madona Devasahayam. The views expressed herein are those of the author and do not necessarily reflect the views of the National Bureau of Economic Research.

NBER working papers are circulated for discussion and comment purposes. They have not been peer-reviewed or been subject to the review by the NBER Board of Directors that accompanies official NBER publications.

(C) 2017 by Robert Z. Lawrence. All rights reserved. Short sections of text, not to exceed two paragraphs, may be quoted without explicit permission provided that full credit, including () notice, is given to the source. 
Recent Manufacturing Employment Growth: The Exception That Proves the Rule.

Robert Z. Lawrence

NBER Working Paper No. 24151

December 2017

JEL No. D24,F16,J21,O14

\begin{abstract}
$\underline{\text { ABSTRACT }}$
This Paper challenges two widely held views: first that trade performance has been the primary reason for the declining share of manufacturing employment in the United States and other industrial economies, and second that recent productivity growth in manufacturing has actually been quite rapid but is not accurately measured. The paper shows that for many decades, relatively faster productivity growth interacting with unresponsive demand has been the dominant force behind the declining share of employment in manufacturing in the United States and other industrial economies. It also shows that since 2010, however, the relationship has been reversed and slower productivity growth in manufacturing has been associated with more robust performance in manufacturing employment. These contrasting experiences suggest a tradeoff between the ability of the manufacturing sector to contribute to productivity growth and its ability to provide employment opportunities.

While some blame measurement errors for the recently recorded slowdown in manufacturing productivity growth, spending patterns in the United States and elsewhere suggest that the productivity slowdown is real and that thus far fears about robots and other technological advances in manufacturing displacing large numbers of jobs appear misplaced.
\end{abstract}

Robert Z. Lawrence

JFK School of Government

79 JFK Street

Cambridge, MA 02138

and NBER

robert_lawrence@harvard.edu

A data appendix is available at http://www.nber.org/data-appendix/w24151 
Manufacturing has played an important role in helping the United States achieve more inclusive income growth. Economic growth depends ultimately on improvements in productivity, and output per worker in manufacturing has historically grown more rapidly than output per worker in the rest of the economy. This has meant that manufacturing has made a disproportionate contribution to income growth. ${ }^{1}$ In addition, manufacturing helped make growth more inclusive because it has provided opportunities for men without a college degree to earn relatively high wages and enter the middle class. In 1970, for example, CPS data indicate that fully 35.6 percent of men without a college degree who held a full-time job worked in US manufacturing, and even in 2015, 17.4 percent of men without a college degree were employed full-time worked in manufacturing. ${ }^{2}$

We like to believe that good things come together, but unfortunately, when it comes to manufacturing, there appears to be a tradeoff between employment and productivity growth. Many see globalization as the most important reason for the erosion in US manufacturing employment, but I will show that for many decades relatively faster productivity growth interacting with unresponsive demand for goods has actually been the dominant force behind the declining share of employment in manufacturing in the United States and other industrial economies. Since 2010, however, the relationship has been reversed and much slower productivity growth in manufacturing has been associated with more robust performance in manufacturing employment and nominal spending on goods.

Price changes tend to reflect total factor productivity changes (Nordhaus 2005). Faster productivity growth in manufacturing will therefore generally lead to lower relative prices for manufactured goods. Figure 1 plots the ratio of (total factor) productivity growth in manufacturing to total factor productivity growth in GDP (TFPMAN/TFPGDP) from 1970 to 2010. It also plots the ratio of the prices for GDP to prices for gross manufacturing value-added (PGDP/PMAN). When (PGDP/PMAN) increases it means that manufacturing goods are becoming relatively cheap, and the figure shows vividly the close association between relative

\footnotetext{
${ }^{1}$ Between 1998 and 2010, manufacturing contributed 29.3 percent of the increase in output due to labor productivity growth but averaged only 11.7 percent of all full-time employment (Bureau of Economic Analysis, https://bea.gov/iTable/iTable.cfm?reqid=19\&step=2\#reqid=19\&step=2\&isuri=1\&1921=survey [accessed on October 31, 2017]).

${ }^{2}$ University of Minnesota, IPUMS-CPS, Current Population Survey Data, https://cps.ipums.org/cps (accessed on October 31, 2017).
} 
increases in productivity in manufacturing and relative declines in prices of manufactured goods. $^{3}$

In principle, the tradeoff between employment and productivity growth is not inevitable. Faster productivity growth means that fewer workers (and other inputs) are needed to produce a given volume of output, but if the quantity demanded is very responsive to lower prices, the volume of goods sold could so increase that more rather than fewer workers would ultimately be employed. While there may be some manufacturing products for which demand is responsive to relative price, for the manufacturing sector as a whole this is not the case. Thus relatively faster productivity growth in manufacturing has led to smaller shares of spending on goods. ${ }^{4}$

In addition, economic growth due to faster productivity raises incomes. Whether this income growth increases employment in goods production depends on how people spend their income gains. As they become richer, people could in theory devote increasing or decreasing shares of their spending to goods. But in practice, as incomes rise, the share spent on goods declines (Boppart 2014). Poor people spend more of their money on goods. They tend to buy more food, clothing, and motorcycles. ${ }^{5}$ Rich people, by contrast, spend more of their money on services. They eat in restaurants, have personal trainers, hire accountants and lawyers, and see psychiatrists. Taken together, therefore, faster productivity growth in the production of goods and more rapid income growth both reduce the share of spending on goods and thus the share of workers required to produce them. ${ }^{6}$

Figure 2 provides estimates of ratios of relative prices, quantities, and values of US final spending on goods versus services and structures. ${ }^{7}$ The data are for final spending on goods and

\footnotetext{
${ }^{3}$ Of course if prices are overstated, productivity growth will be understated, both nonetheless both would still move together.

${ }^{4}$ The inelastic nature of the demand for manufactured goods as a whole is not really surprising, since we are considering the demand for an entire sector. We expect elasticities to be higher at low levels of aggregation. For example, Toyotas might be close substitutes for Hondas, but automobiles as a group will be less substitutable for other transportation vehicles such as motorcycles, trains, and buses, and in turn all manufactured goods less substitutable for all services or agricultural products.

${ }^{5}$ Fajgelbaum and Khandelwal (2016) show that because the poor tend to spend higher shares of their incomes on goods and goods are more traded than services, this also means that they enjoy disproportionate gains from trade.

${ }^{6}$ Boppart $(2014,2190)$ estimates the elasticity of substitution between goods and services as 0.596 and the expenditure elasticity in consumption at .78 . He finds that between 1946 and 2011 changes in incomes and relative prices each accounted for about half of the decline in the share of spending on goods.

${ }^{7}$ Since GDP is defined as Consumption (C) plus Investment (I) plus Government Spending (G) plus Exports (X) minus Imports $(M)$, I can obtain total US spending (i.e., $C+I+G)$ by subtracting the trade balance $(X-M)$ from GDP. Since separate data for goods GDP and merchandise trade are also available I can obtain similar estimates of spending on goods. By subtracting spending on goods from total spending I obtain nominal spending on services and structures. Similarly using the data expressed in 2009 prices I can obtain estimates of the quantities of goods and
} 
thus reflect not only the value-added in manufacturing but also the value-added in the raw materials used to produce the goods and the additional costs required to distribute them to final consumers. Thus they only reflect the demand for manufacturing value-added under the assumption that the margins for inputs and distribution remain constant. Nonetheless, they are revealing.

The data are expressed in logarithms and can thus be interpreted as percentages. The top line shows the decline in the prices of goods relative to services over the 69-year period-by 136 $\log$ points or just less than 2 percent per year. By contrast the bottom line shows the increase in quantities of goods purchased relative to services - by $66 \log$ points or just less than 1 percent per year. The result is that the value of spending on goods has fallen relative to the value of spending on services and structures by roughly 1 percent annually (the middle line). The figure shows that Americans have responded to declining relative prices of goods and higher incomes by spending more of their money on services.

The decline in relative prices of goods and the rise in incomes do not boost demand for goods enough to offset the decline in the demand for labor and other inputs due to relatively faster productivity growth in the production of goods. ${ }^{8}$ Therefore the share of goods in spending and the share of inputs used in the production (and consumption) of goods both decline. This impact can be seen vividly in US consumption spending, which on average accounted for 62 percent of all national spending between 1947 and 2017. Over this period the share of consumption spending on goods declined from 62 to 33 percent. $^{9}$

This account relating the effects of US spending to US output of goods has abstracted from the impact of trade. If the United States were a closed economy, this would be all that matters. In reality, given domestic spending, a trade surplus in manufactured goods would add to manufacturing employment and a deficit would subtract from it. ${ }^{10}$ But the account of the United States as a basically closed economy fits the facts closely until the 1970s. The US manufacturing employment share began declining in the 1950s-long before the economy was exposed to trade.

services plus structures that have been purchased. I use the separately reported price indexes for goods and services to obtain relative goods prices.

${ }^{8}$ This statement implicitly assumes Hicks-neutral technical change.

${ }^{9}$ Bureau of Economic Analysis, https://bea.gov/iTable/iTable.cfm?reqid=19\&step=2\#reqid=19\&step=3\&isuri=1\&1921=survey\&1903=65 (accessed on October 31, 2017).

${ }^{10}$ As emphasized by Matsuyama (2009), for example, in a small price-taking open economy, demand could be infinitely elastic and faster productivity growth could then increase employment. 
Moreover, the rate at which the US manufacturing employment share has fallen over the past three decades as the economy globalized further - about 0.4 percentage points per year-is remarkably similar to the rate at which it fell in the 1960s and 1970s. This similarity suggests that the forces that operated in the early years continue to dominate. As shown in figure 3 , when a trend line fitted to manufacturing employment data from 1960 to 1980 is projected out to 30 years, it precisely predicts the share of manufacturing employment in 2010. Without knowing about China's rise, the North American Free Trade Agreement (NAFTA), or the formation of the World Trade Organization (WTO), a forecaster in 1980 would have been able to accurately predict the number of workers employed in manufacturing in 2010 without almost any error! ${ }^{11}$

Donald Trump has blamed "offshoring and trade" for declines in manufacturing employment, singling out what he considers are flawed trade agreements as the major driver of these developments. While there is evidence that the US trade deficit has contributed to some of the losses of manufacturing jobs since 2000, far more powerful even during this period has been the impact of faster productivity growth interacting with unresponsive demand for goods. For example, 985,000 US manufacturing jobs estimated to have been lost due to Chinese imports between 1999 and 2011 (Acemoglu et al. 2016) represent less than a fifth of the total loss of over 5 million US manufacturing jobs over the same period. ${ }^{12}$ In Edwards and Lawrence $(2013,83)$, we estimate that because of rapid productivity growth in manufacturing, the manufacturing employment content of the US trade deficit in 2010 (2.7 million jobs) was actually lower than that estimated for 2000 (3.3 million jobs). In other words, rapid productivity growth in manufacturing implies that over time any given trade deficit translates into fewer jobs.

\footnotetext{
${ }^{11}$ Manufacturing employment performance was unusual after 2000 however because in addition to a declining share, absolute employment also fell. However, as shown in Lawrence and Edwards (2013; pp3-4) this decline was predictable given the historic relationship between changes in manufacturing employment and changes in total employment. Nager (2017) has objected to the fitting of a linear rather an exponential trend on the grounds that a linear curve implies eventually manufacturing employment would disappear. However, the linear trend has a much better R-squared fit than the exponential trend and as noted the specification using percentage changes in manufacturing and in the rest of the economy also fits the data out of sample between 2000 and 2010 almost perfectly.

12 “Applying this direct plus full input-output measure of exposure increases our estimates of trade-induced job losses for 1999-2011 to 985,000 workers in manufacturing alone and to 1.98 million workers in the entire economy" (Acemoglu et al. 2016, S145). A very similar job loss estimate of 0.8 million manufacturing jobs is obtained by Caliendo, Dvorkin, and Paro (2017, abstract). Hicks and Devaraj $(2017,6)$ estimate that that between 2000 and 2010, 13.4 percent of manufacturing jobs $(750,000)$ lost were due to trade.
} 


\section{RECENT US EXPERIENCE}

As can be seen in figure 3, since about 2010, the long-run trend line no longer fits the data. While still declining, manufacturing's share in US employment since 2010 has fallen much less than its long-run trend. Indeed, the small drop in the share of just 0.29 percentage points over the six-year period between 2010 and 2016 is less than the 0.40 percentage point annual average that was typical over the prior five decades. Recent manufacturing employment behavior has also been radically different than it was in the early 2000s. In the economic recovery after the 2001 recession, manufacturing employment did not increase at all, but, after reaching a trough in 2010, it had increased by 1.6 million jobs by 2016 .

One might speculate that this recent jobs performance indicates that US manufacturing is becoming more internationally competitive and that jobs are returning ("on-shoring") as a result of lower US energy prices, higher Chinese wages, and innovations such as 3-D printing. But recent US trade performance does not support this interpretation. Between 2010 and 2016, the US trade deficit in manufactured goods actually increased from $\$ 412$ billion to $\$ 639$ billion-by about 0.7 percent of GDP. ${ }^{13}$ While care should be taken when providing causal interpretations to trade deficits after the fact, ${ }^{14}$ this increase in the trade deficit suggests that trade, if anything, was probably a drag on manufacturing employment.

Another possibility could be that demand and employment represent an unsual temporary snap back from the deep US recession, but by 2016 this effect should have dissipated. Instead, slow productivity growth appears to be the source of the relative strength in manufacturing employment growth over the full period. As is illustrated in figure 4, since 2010 the rapid productivity growth in manufacturing has ground to a halt: Between 2010 and 2016, output per full-time employee in manufacturing declined by 2.2 percent. This pace is far below the manufacturing labor productivity growth of 4.3 percent achieved annually between 2000 and 2010. ${ }^{15}$ Moreover, according to the more comprehensive measure of productivity growth-

\footnotetext{
${ }^{13}$ Since value-added per full-time equivalent employed in manufacturing has increased from $\$ 162,993$ to $\$ 180,577$ per worker over the same period, the employment equivalence of the manufacturing trade deficit has increased by a million, up from 2.5 million to 3.5 million jobs.

${ }^{14}$ For a discussion of the pitfalls of assuming trade deficits necessarily lead to employment loss, see Edwards and Lawrence (2013, 33-42).

${ }^{15}$ The computer industry was a major driver of manufacturing productivity, and as emphasized by Baily and Bosworth (2014), a major part of that industry has moved abroad, inevitably reducing average output and
} 
multifactor productivity growth (MFP) — manufacturing's productivity growth increased at an annual average rate of 1.3 percent between 1987 and 2008 and by just 8/10ths of a percent between 2008 and 2010, then declined by 5.8 percent between 2010 and 2015, falling by 2.8 percent in 2015 alone. $^{16}$

The relative prices of manufactured goods are consistent with the productivity data. Information technology products led the surge in productivity growth in manufacturing that began in 1995 (Jorgenson 2001). But that surge peaked in 2005 and lasted through about 2010 and more recently the rate at which producer prices of semi-conductors and computers have been falling has decelerated. ${ }^{17}$

A similar story is reflected by broader price measures of manufactured goods. As shown in figure 5, the deflator for the manufacturing industry relative to the GDP deflator declined at an annual rate of 2.1 percent between 1997 and 2010, but between 2010 and 2016 it actually increased by 2.8 percent. Similarly the GDP deflators for finished goods prices compared with services declined at an annual rate of 3 percent between 2000 and 2010 but by just 1.7 percent per year between 2010 and 2016.

The recent behavior of spending on goods has also been unusually strong. Over the long run (1947 to 2015), nominal (final) spending on goods has fallen by about 1 percent per year relative to nominal spending on services (figure 2). But the ratio of consumer spending on nonenergy goods to spending on services was quite similar in 2010 and 2016 (figure 6).

In sum, in recent years we have seen (1) slower declines in the share of manufacturing employment; (2) slower productivity growth in manufacturing; (c) higher relative prices for manufacturing value-added rather than lower prices; and (d) relative prices for goods at the consumer level falling more slowly. In response, spending on goods compared with services is also falling much less rapidly than before. These outcomes are all predictable if there is a relative slowdown in productivity growth in manufacturing and demand for goods is price inelastic.

productivity growth, both because measuring productivity growth in computers is difficult and because its share in output is declining.

${ }^{16}$ BLS Multifactor Productivity News Release, July 12, 2017, www.bls.gov/news.release/pdf/prod5.pdf (accessed on October 31, 2017).

${ }^{17}$ For example, the Producer Price Index for microprocessors, which had been declining at approximately 10 percent annually between 1990 and 1995, fell by an astounding 53 percent annually between 1995 and 2000, and by 37 percent between 2000 and 2005, 21 percent between 2005 and 2010 and just 4 percent annually from 2010 to 2014 , respectively. See Inflation and Prices Data, Bureau of Labor Statistics, www.bls.gov/data/\#prices (accessed on March 19, 2017). 


\section{INTERNATIONAL EVIDENCE}

Similar negative trends in the share of workers in manufacturing are evident in all industrialized countries (table 1). Between 1973 and 2010 the average decline of the US employment share in manufacturing of 0.40 percentage points is just about the same as the average decline of 0.39 percentage points for all the countries in the sample, and the 2.4 percent annual decline in the share is close to the 2.0 percent decline in the average share.

Moreover, it is noteworthy that the sample showing downward trends in manufacturing employment includes countries such as Germany, Japan, and Italy, which have had trade surpluses in manufacturing trade that between 1973 and 2010 averaged 7.6, 6.2, and 4.2 percent of their GDPs, respectively (Lawrence and Edwards 2013). The experience of these countries shows that an increased trade surplus in manufactured goods can lead to an increase in the level of manufacturing employment - Germany, Italy, and Japan, for example, clearly have higher shares of manufacturing employment than the other countries - but as productivity growth increases over time, the employment content of a given surplus (or deficit) will decline and eventually the long-run trends that reflect the interaction between productivity growth and demand will tend to dominate the outcomes.

It is also noteworthy that the United States is not unique in having had a slower decline in the share of manufacturing employment between 2010 and 2016 than it experienced earlier. As shown in table 1 , on average the percentage point decline in manufacturing in all nine of the industrialized countries in the sample has been just 35 percent of the average annual decline between 1973 and 2010, and the average annual percentage decline in the manufacturing employment share in the nine countries has been about half that recorded between 1973 and 2010. Indeed, only in Australia has the annual percentage decline between slightly faster.

The international evidence also shows that the United States is not unique in having a declining share of consumer spending on goods over long run. As shown in table 2, in a sample of nine OECD countries - data on Australia are not available - between 1995 and 2010, for example, the average annual rate of decline in the share of consumer spending on goods was 0.56 percent per year. By contrast, between 2010 and 2014 (the latest OECD data currently available) the share of consumer spending on goods in the sample actually increased by an average of 0.15 percent and in five of the nine countries the share increased by an average of .50 percent. 


\section{WHAT ARE THEY DOING WITH THE ROBOTS?}

The changed spending responses can also help shed light on another controversy that relates to productivity growth (Feldstein 2017; Fernald 2012; Baily, Manyika, and Gupta 2013; Branstetter and Sichel 2017). On the one hand, many productivity experts claim we are living in period of very slow productivity growth. Robert Gordon (2012), a leading techno-pessimist, has vividly described how the information technology revolution that stimulated productivity growth between 1995 and 2005 has run its course and that our ability to sustain strong economic growth has run into significant headwinds. Tyler Cowen (2011) agrees that we have already picked the low-hanging fruit that can improve living standards. These views are consistent with data and the consensus of professional forecasters. For example, as noted by Byrne, Oliner, and Sichel (2017, 24), a survey of professional forecasters shows that while in 2007 they had projected that the United States would achieve long-run growth in labor productivity of 2.3 percent, by 2012-13, their projections had declined to an average of 1.9 percent.

On the other hand are claims that we are going through a new era in which the pace of change is so rapid that it deserves a new name such as "the fourth industrial revolution" (Schwab 2016) or "the second machine age" (Brynjolfsson and McAfee 2014). These techno-optimists see a world that is awash in new technologies that will bring about fundamental economic and social changes. They point to improvements in information processing that are revolutionizing areas such as artificial intelligence, big-data analytics, precision medicine, machine learning, robotics, 3-D printing, cloud computing, the internet of things, and autonomous vehicles that are capable of unleashing a surge in productivity and accelerate economic growth. ${ }^{18}$ Indeed, many now view the luddites more favorably and are concerned that the ability to digitize technology will displace both skilled and unskilled workers and make it increasingly difficult to earn a living wage. This has prompted proposals to deal with these prospective inequities either by having the workers own the machines (Freeman 2016) or by slowing their progress through the taxation of capital (Piketty 2013).

The productivity facts, thus far, are on the side of the techno-pessimists, but some technooptimists claim that the official data understate the quality of recent innovations and the

\footnotetext{
${ }^{18}$ For additional discussion of emerging technologies in manufacturing, see Baily and Bosworth $(2014,19-22)$. 
improvements they have enabled. But it has always been difficult to measure productivity growth, especially when it involves radically new products and technologies, so that to make the case for mismeasurement, it is necessary to claim not simply that there is mismeasurement but also that mismeasurement has become increasingly worse. ${ }^{19}$

One response to mismeasurement is developing better methodologies for measuring prices. ${ }^{20}$ But another is to examine the data on spending. Ultimately the buyers are the best judges of quality. Buyers will respond to true prices rather than nominal prices. If true prices are actually lower than official prices, and demand is inelastic, nominal spending should fall in response to productivity improvements. Many advances such as robotics, 3-D printing, the internet of things, big data, and the cloud should be improving productivity in the production and distribution of goods. If, in reality, these have accelerated the relative productivity growth in goods production, the share of nominal spending on goods should fall even faster than before. The share of total US nominal spending on goods $(C+I+G)$ declined from 36.5 percent in 2000 to 32.8 percent in 2008. However, in 2016 the share was 32.9 percent, almost exactly what it was in 2008. Similarly, in 2016 the share of nominal spending on goods in total consumption spending was 32.1 percent compared with 33.7 percent in 2008 and 36.1 percent in $2000 .^{21}$ This suggests that the recent relative slowdown in manufacturing productivity is real.

\section{CONCLUDING COMMENT}

Manufacturing has played a special role in economic growth and it is not surprising that many governments currently have major initiatives that aim at promoting advanced manufacturing technology. Ultimately economic progress rests upon technological innovation, and if they prove

\footnotetext{
${ }^{19}$ Feldstein $(2017,153-56)$ emphasizes the problems that result from understating productivity growth when new goods or services are introduced. This could mean that productivity growth will be measured as slowing down especially during innovative periods when more new products are being introduced.

${ }^{20}$ Byrne, Oliner, and Sichel (2017) argue that the official producer price index has understated recent improvements in information technology and develop new hedonic price measures that take account of improvements in the performance of a given set of tasks valued by users based on tests undertaken by the Standard Performance Evaluation Corporation. Between 2009 and 2013, for example, while the producer price index for microprocessors declined annually by just 6 percent, the authors estimate annual declines (i.e., improvements in performance) of 42 percent using their measures based on performance. Byrne and Corrado (2017) estimate that between 2004 and 2014 similar improvements took place in computer servers and storage (26.1 percent annual price declines), PCs (23.7 percent annual price declines), and data networking (12.1 percent annual price declines).

${ }^{21}$ See footnote 7 for methodology and source.
} 
successful these initiatives could provide a much needed boost to economic growth. But these initiatives are also often motivated by the claim that they will increase blue collar employment and the evidence in this paper suggests a painful tradeoff. Faster productivity growth generated by advanced manufacturing technology may lead to more rapid growth, but it is unlikely to be inclusive.

\section{REFERENCES}

Acemoglu, Daron, David Autor, David Dorn, Gordon H. Hanson, and Brendan Price. 2016. Import Competition and the Great US Employment Sag of the 2000s. Journal of Labor Economics 34, no. S1 (Part 2, January): S141-S198.

Baily, Martin N., James L. Manyika, and Shalabh Gupta. 2013. U.S. Productivity Growth: An Optimistic Perspective. International Productivity Monitor 25. Available at www.csls.ca/ipm/ipm25.asp (accessed on October 31, 2017).

Baily, Martin Neil, and Barry P. Bosworth. 2014. US Manufacturing: Understanding its Past and Its Potential Future. Journal of Economic Perspectives 28, no. 1 (Winter): 3-26.

Boppart, Timo. 2014. Structural Change and the Kaldor Facts in a Growth Model with Relative Price Effects and Non-Gorman Preferences. Econometrica 82, no. 6: 2167-96.

Branstetter, Lee G., and Daniel Sichel. 2017. The Case for an American Productivity Revival. PIIE Policy Brief 17-26. Washington: Peterson Institute for International Economics.

Brynjolfsson, Erik, and Andrew McAfee. 2014. The Second Machine Age: Work, Progress and Prosperity in a Time of Brilliant Technologies. W. W. Norton \& Company.

Byrne, David M., and Carol Corrado. 2017. ICT Prices and ICT Services: What Do They Tell Us about Productivity and Technology? Finance and Economics Discussion Series 2017-015. Washington: Board of Governors of the Federal Reserve System. Available at https://doi.org/10.17016/FEDS.2017.015 (accessed on October 31, 2017).

Byrne, David M., S. D. Oliner, and D. E. Sichel. 2017. How Fast Are Semiconductor Prices Falling? Finance and Economics Discussion Series 2017-005. Washington: Board of Governors of the Federal Reserve System.

Caliendo, Lorenzo, Maxmiliano Dvorkin, and Fernando Paro. 2017. Trade and Labor Market Dynamics: General Equilibrium Analysis of the China Trade Shock. Working Paper 2015-009D (revised). St. Louis, MO: Federal Reserve Bank of St. Louis.

Cowen, Tyler. 2011. The Great Stagnation: How America Ate All the Low-Hanging Fruit of Modern History, Got Sick, and Will (Eventually) Feel Better Again. Dutton. 
Edwards, Lawrence, and Robert Z. Lawrence. 2013. Rising Tide: Is Growth in Emerging Economies Good for the United States? Washington: Peterson Institute for International Economics.

Fajgelbaum, Pablo D., and Amit K. Khandelwal. 2016. Measuring the Unequal Gains from Trade. Quarterly Journal of Economics 131, no. 3 (August): 1113-80.

Feldstein, Martin. 2017. Underestimating the Real Growth of GDP, Personal Income and Productivity. Journal of Economic Perspectives 31, no 2: 145-64.

Fernald, John. 2012. Productivity and Potential Output before, during, and after the Great Recession. Federal Reserve Bank of San Francisco Working Paper 2012-18. Federal Reserve Bank of San Francisco. Available at www.frbsf.org/publications/economics/papers/2012/wp1218bk.pdf (accessed on October 31, 2017).

Freeman, Richard. 2016. Who Owns the Robots Rules the World. Harvard Magazine (MayJune). Available at http://harvardmagazine.com/2016/05/who-owns-the-robots-rules-the-world.

Gordon, Robert J. 2012. Is U.S. Economic Growth Over? Faltering Innovation Confronts the Six Headwinds. NBER Working Paper 18315. Cambridge, MA: National Bureau of Economic Research. Available at www.nber.org/papers/w18315_(accessed on October 31, 2017).

Hicks, Michael, and Srikant Devaraj. 2017. The Myth and the Reality of Manufacturing in America. Center for Business and Economic Research, Ball State University.

Jorgenson, Dale. 2001. Information Technology and the U.S. Economy. American Economic Review 90, no. 1 (March): 1-32.

Jorgenson, Dale W., Mun S. Ho, and Jon Samuels. 2012. A Prototype Industry- Level Production Account for the United States, 1947- 2010. Paper presented at the Second World KLEMS Conference, Harvard University, August 9.

Lawrence, Robert Z., and Lawrence Edwards. 2013. US Employment Deindustrialization: Insights from History and the International Experience. PIIE Policy Brief 13-27. Washington: Peterson Institute for International Economics.

Matsuyama, Kiminori. 2009. Structural Change in an Interdependent World: A Global View of Manufacturing Decline. Journal of the European Economic Association 7, no. 2-3 (April-May): 478-86.

Nagar, Adams 2017 “Trade versus Productivity: What Caused U.S. Manufacturing's Decline and How to Revive It" Washington DC: Information Technology \& Information Foundation

Nordhaus, William. 2005. The Sources of the Productivity Rebound and the Manufacturing Employment Puzzle. NBER Working Paper 11354. Cambridge, MA: National Bureau of Economic Research. 
Piketty, Thomas. 2013. Capital in the Twenty-First Century. Cambridge, MA: Harvard University Press.

Schwab, Klaus. 2016. The Fourth Industrial Revolution. Cologny/Geneva: World Economic Forum.

Table 1 Share of employment in manufacturing, selected countries (percent)

\begin{tabular}{|c|c|c|c|c|c|c|c|c|c|c|}
\hline Year & United States & Australia & Canada & France & Germany & Italy & Japan & Netherlands & United Kingdom & Average \\
\hline 1973 & 24.75 & 23.35 & 22.00 & 28.88 & 36.74 & 27.86 & 27.78 & 25.29 & 32.06 & 27.63 \\
\hline 1990 & 16.77 & 14.42 & 15.79 & 21.27 & 31.62 & 22.56 & 24.33 & 19.08 & 22.13 & 20.88 \\
\hline 2000 & 14.35 & 12.05 & 15.26 & 17.87 & 23.86 & 22.91 & 20.66 & 14.85 & 14.82 & 17.40 \\
\hline 2010 & 10.13 & 8.90 & 10.27 & 13.32 & 20.10 & 18.87 & 16.95 & 10.64 & 9.85 & 13.23 \\
\hline 2016 & 10.17 & 7.51 & 9.37 & 12.15 & 19.15 & 18.23 & 16.10 & 9.52 & 9.46 & 12.41 \\
\hline \multicolumn{11}{|c|}{ Average annual change in employment share (percentage points) } \\
\hline 2010-1973 (1) & -0.40 & -0.39 & -0.32 & -0.42 & -0.45 & -0.24 & -0.29 & -0.40 & -0.60 & -0.39 \\
\hline $2016-2010(2)$ & 0.01 & -0.23 & -0.15 & -0.19 & -0.16 & -0.11 & -0.14 & -0.19 & -0.07 & -0.14 \\
\hline Ratio (2)(1) & -0.02 & 0.59 & 0.47 & 0.46 & 0.35 & 0.44 & 0.49 & 0.47 & 0.11 & 0.35 \\
\hline \multicolumn{11}{|c|}{ Average annual change in employment share (percent) } \\
\hline $2010-1973(1)$ & -2.4 & -2.6 & -2.0 & -2.1 & -1.6 & -1.0 & -1.3 & -2.3 & -3.1 & -2.0 \\
\hline $2016-2010(2)$ & 0.1 & -2.8 & -1.5 & -1.5 & -0.8 & -0.6 & -0.9 & -1.8 & -0.7 & -1.1 \\
\hline Ratio (2)(1) & 0.0 & 1.1 & 0.7 & 0.7 & 0.5 & 0.5 & 0.6 & 0.8 & 0.2 & 0.5 \\
\hline
\end{tabular}

Sources: Organization for Economic Cooperation and Development; Bureau of Labor Statistics.

Source: OECD and BLS 
Table 2 Share of spending on goods in total consumption spending, selected advanced economies (percent)

\begin{tabular}{|c|c|c|c|c|c|}
\hline \multirow[t]{2}{*}{ Country } & \multirow[t]{2}{*}{1995} & \multirow[t]{2}{*}{2010} & \multirow[t]{2}{*}{2014} & \multicolumn{2}{|c|}{ Average annual change } \\
\hline & & & & 1995-2010 & 2010-2014 \\
\hline United States & 37 & 34 & 35 & -0.62 & 0.59 \\
\hline Canada & 47 & 43 & 43 & -0.64 & 0.05 \\
\hline France & 45 & 43 & 46 & -0.25 & 1.35 \\
\hline Germany & 49 & 47 & 47 & -0.25 & -0.20 \\
\hline Italy & 46 & 40 & 40 & -0.97 & 0.37 \\
\hline Japan & 58 & 50 & 49 & -0.90 & -0.54 \\
\hline Korea & 51 & 47 & 47 & -0.46 & -0.02 \\
\hline Netherlands & 51 & 47 & 47 & -0.60 & 0.15 \\
\hline United Kingdom & 47 & 45 & 44 & -0.37 & -0.36 \\
\hline Average & 48 & 44 & 44 & -0.56 & 0.15 \\
\hline
\end{tabular}

Source: OECD National Income Accounts. 


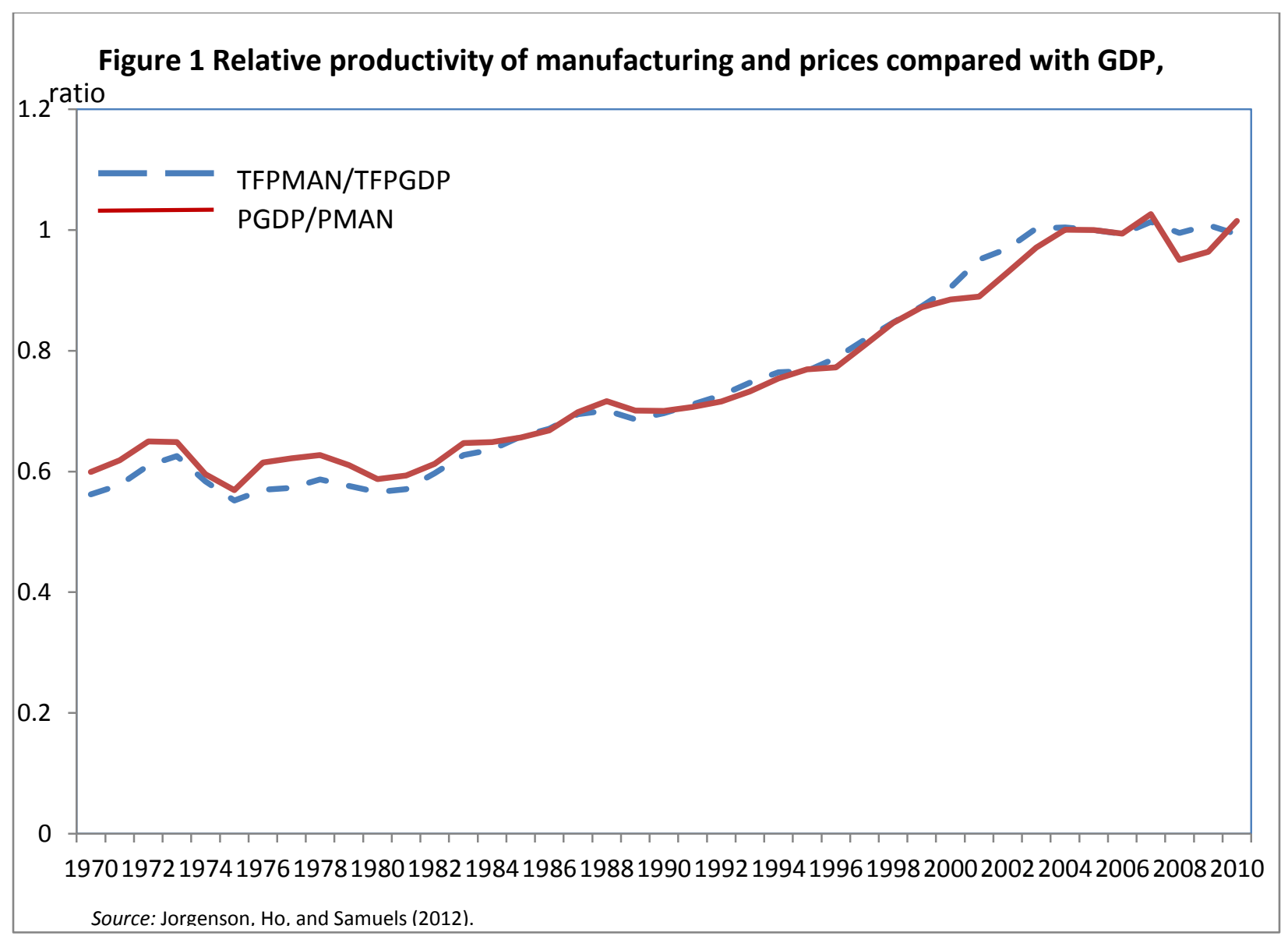




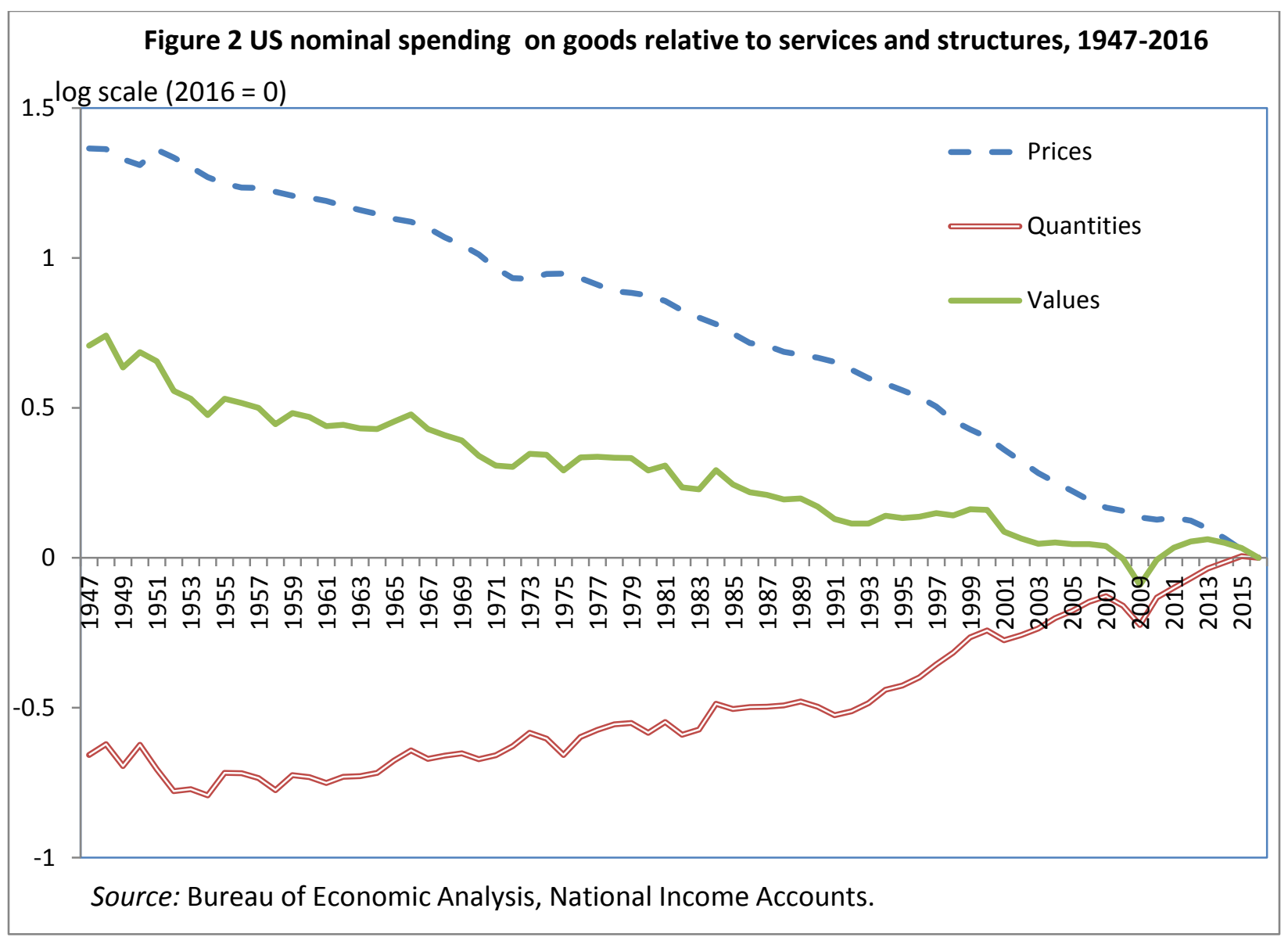




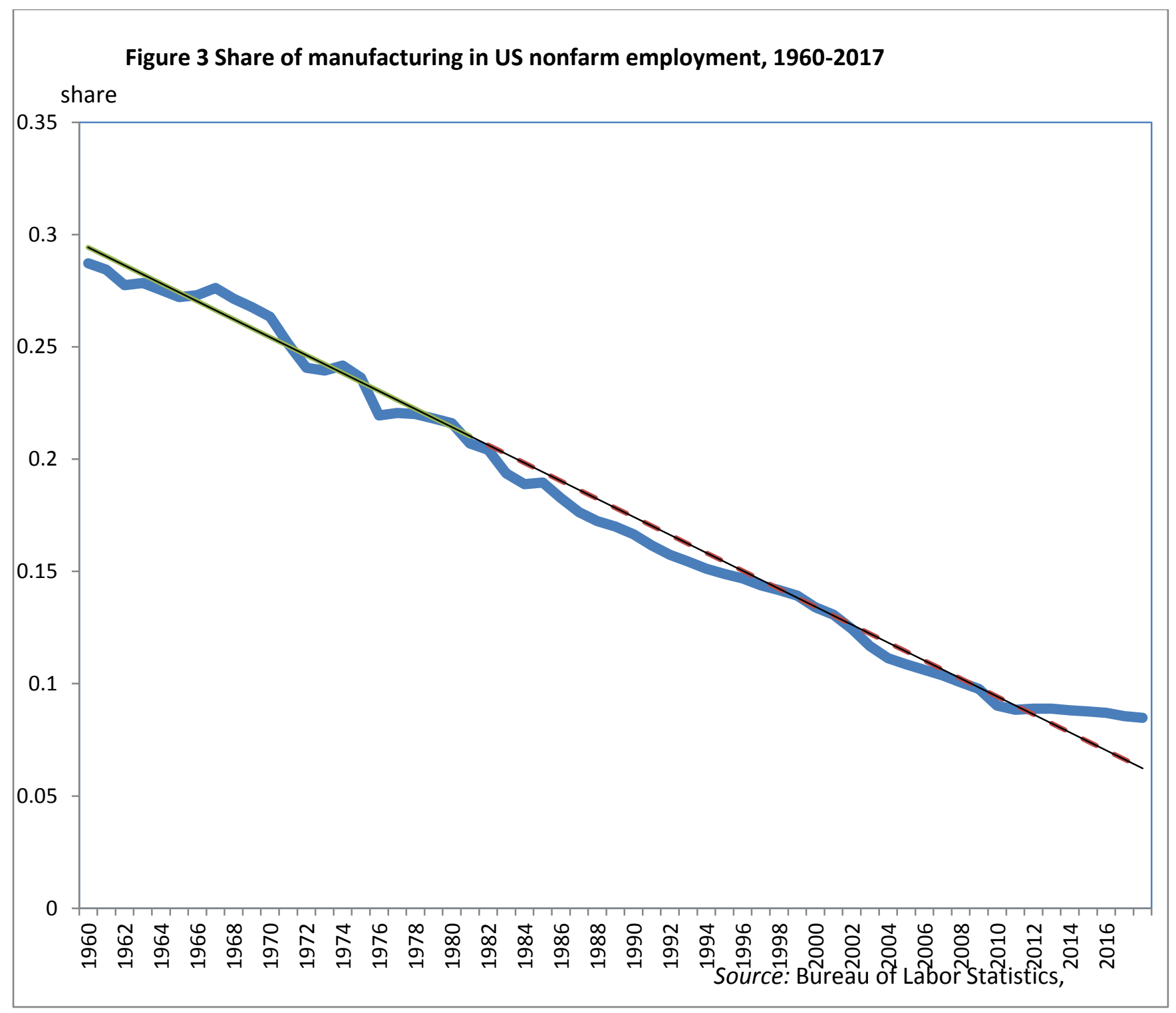




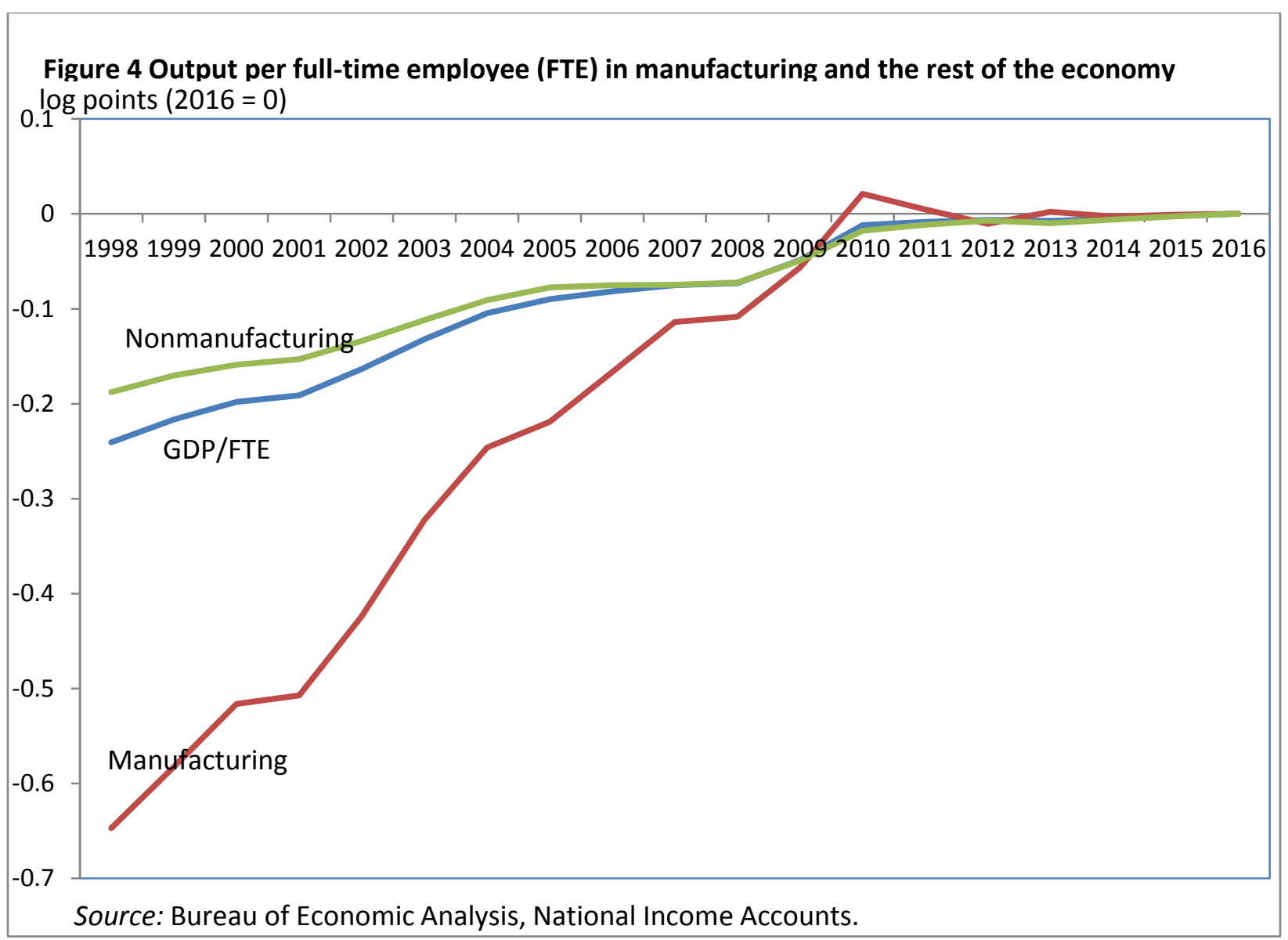




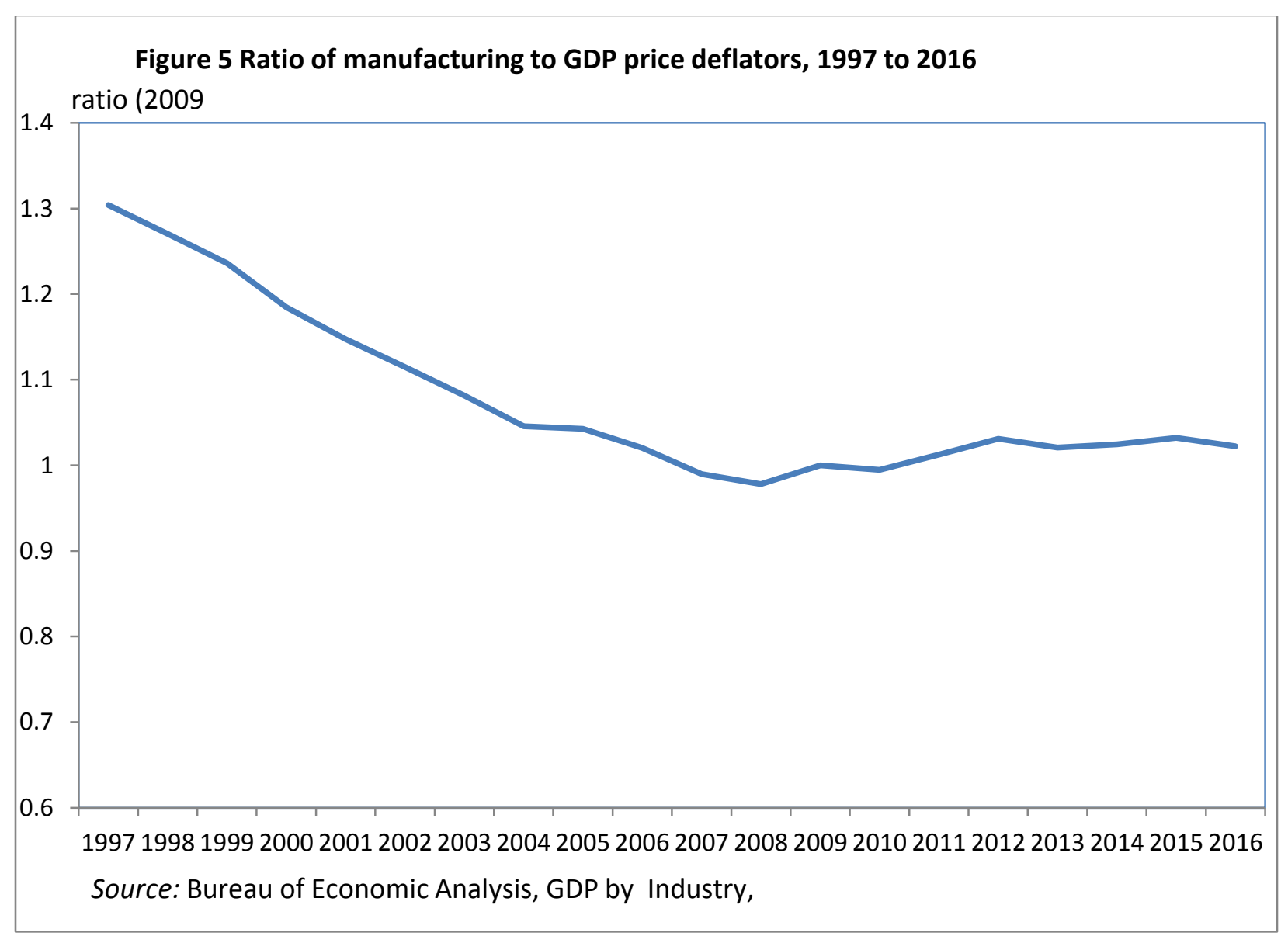




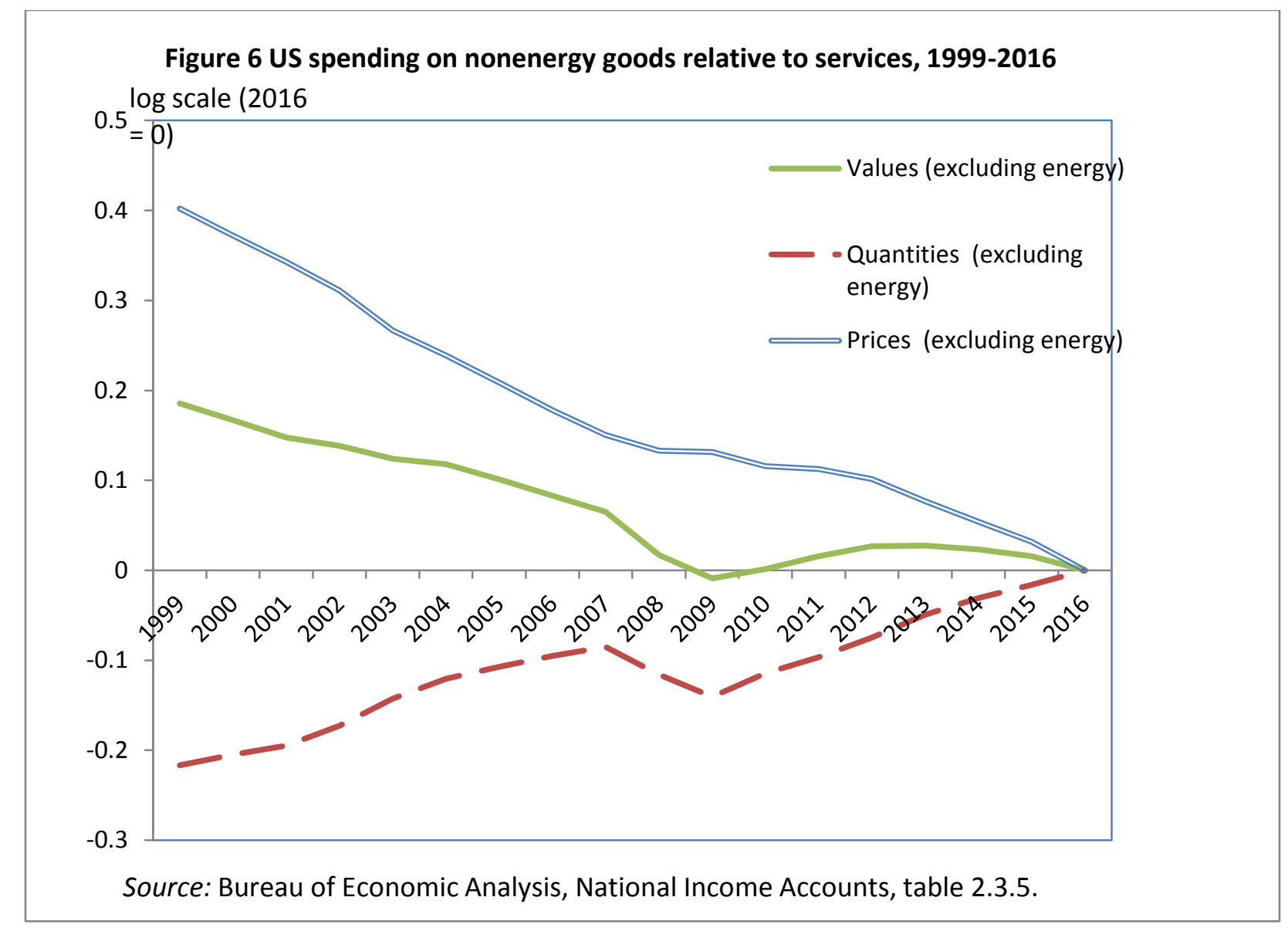

